\title{
Z3 Research Sware \\ A Case Report of Isolated Pigmentosus Atrophic Lichen Planus on the Supramaxillary Area: A New Variant $₫$
}

\author{
Ningyuan Liu \\ Beijing University of Chinese Medicine \\ Ruiheng Zhao \\ Beijing University of Chinese Medicine \\ Danni Su \\ Peking University Health Science Centre \\ Xiaoyan Zhang ( $\nabla$ superfawn2020@163.com ) \\ China-Japan Friendship Hospital https://orcid.org/0000-0002-8786-4164
}

\section{Case report}

Keywords: Lichen planus pigmentosus, Atrophic lichen planus, Supramaxillary area, Topical corticosteroids, Calcineurin inhibitors

Posted Date: December 1st, 2020

DOI: https://doi.org/10.21203/rs.3.rs-115346/v1

License: (1) This work is licensed under a Creative Commons Attribution 4.0 International License. Read Full License 


\section{Abstract}

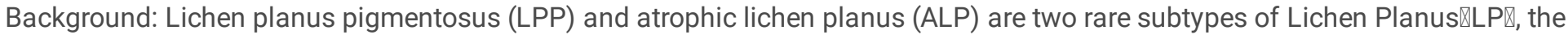
former is characterized by epidermal atrophy and the latter by over pigmentation. LP with both of the above manifestations has few reports and there is a lack of treatment experience.

Case presentation: We herein reported a 22-year old girl with a complaint of a sharply edged brown plaque on the supramaxillary area with pain and itchy for 6 months. The skin biopsy sample from the forehead revealed thinning of epidermal ridges, liquefaction degeneration of basal cells, loss of cuticular process, lichenoid lymphocytic infiltration and incontinence of pigment as well as numerous melanophages. It was diagnosed as atrophic Lichen planus pigmentosus (ALPP), and the plaque was completely cleared after 10 months of Alternating topical corticosteroids or calcineurin inhibitors.

Discussion and Conclusions: ALPP might be an independent variant of LP or LPP that causes significant epidermal atrophy in the degenerative phase. This case revealed the special type of LP and provided a clinical reference for the treatment.

\section{Background}

Lichen planus (LP) is a chronic inflammatory and self-limiting skin condition with phenotypic heterogeneity. Lichen planus pigmentosus (LPP) and atrophic lichen planus (ALP) are two different subtypes of LP, the former is characterized by epidermal atrophy and the latter by over pigmentation. In addition, some cases with LPP have mild epidermal atrophy, and some ALP have slight pigmentation. We report a special case with the characteristics of both subtypes significantly which was diagnose as atrophic Lichen planus pigmentosus (ALPP) and successfully treated with topical glucocorticoids and calcineurin inhibitors.

\section{Case Presentation}

A 22-year-old girl with a history of brown plaque on her face and occasional pain and itching for 6 months presented to our hospital. The brown plaque has been slowly progressed to a $2 \mathrm{~cm} \times 1 \mathrm{~cm}$ black-brown atrophic patch. She denied any history of preceding rash, fevers, chills, trauma,medical application and long time exposure to sunlight. There was no relevant past medical, family, drug or allergy history. On examination the lesion appeared as black-brown with middle atrophy and sharply raised border, and was presented on the right supramaxillary area of the girl (Fig. 1卬A). Laboratory tests were negative for hepatitis B, syphilis, hepatitis $\mathrm{C}$ and HIV.

The patient was initially diagnoses as LP and differential diagnosis showed drug eruption and granuloma annulare. Interestingly, pathological section of the lesion showed a mixture of LPP and ALP, which are characterized by epidermal basket - like keratinization, hyperkeratosis, wedge-shaped hypergranulosis, thinning of epidermal ridges, liquefaction degeneration of basal cells, loss of cuticular process, lichenoid lymphocytic infiltration and incontinence of pigment as well as numerous melanophages within the papillary and superficial and middle of the dermis. (Figure.2)

The patient was given $1 \%$ pimecrolimus cream for topical application for 1 month at the beginning, and her itching was relieved, but the skin lesions showed no significant improvement. So, she was switched to $0.03 \%$ tacrolimus ointment for 1 month and the skin lesions became lighter in color and slightly reduced in area by $10 \%$, and successively switched to $1 \%$ mometasone furfurate cream, desonide cream, chlorobetasol ointment, halometasone cream, triamcinolone acetonide and econazole nitrate cream every

2 weeks for 6 months, than changing to mucopolysaccharide polysulfonate cream, and calcitriol ointment for topical application 2 months. During this period, pigmentation and epidermal atrophy showed continuous improvement (Fig. 1B, C), and the patient's skin lesions were completely resolved after follow-up at 10 months (Fig. 1D).

\section{Discussion And Conclusions}

This case challenges our diagnosis and treatment because ALP and plaque-type LPP have similarities. According to our literature review, pigmentation is seen in nearly half of the ALP cases, while mild epidermal atrophy is seen in LPP cases. There are also significant differences between the two: the plaque boundary of LPP is unclear, while that of ALP plaque is depressed in the middle, elevated around and the boundary is clear; in LPP, more melanophages or pigment cells can be present, and the degree of 
epidermal atrophy remains mild; ALP has significant epidermal process disappearance, while pigment incontinence is mild. Both epidermal atrophy and pigmentary incontinence were evident in this patient, and so it was diagnosed as ALPP, which might be an independent variant of LP or LPP with significant epidermal atrophy in the degenerative phase.

LPP is a rare LP variant that is more commonly seen in the sun-exposed areas such as face, neck, and arms and can also be seen in flexed sites. The disease mainly affects the patients with skin types III to IV, and is more commonly seen in India, Latin America, Asia, and Africa, and is rare in Caucasians. It is caused by hepatitis $C$ virus, endocrine diseases and autoimmune diseases, cosmetics and environmental pollution stimuli. LPP is characterized by symmetrically distributed dark brown to gray or grayish blue-gray color round and oval spots with irregular and ill-defined borders that eventually enlarges and coalesces, asymptomatic or mildly pruritic, and have a chronic course of 6 months to 3 years. According to pigmentation findings, it can be divided into diffuse, reticular, blotchy, and perifollicular patterns [1-3]. The main characteristic pathological findings of LPP are basal cell liquefaction and lichenoid infiltration. Moreover, perivascular lymphocytic infiltrate and pigment incontinence in the superficial dermis also could be seen in some cases. Epidermal hyperkeratosis and mild epidermal atrophy are also seen in some cases [4]. The infiltration pattern of LPP changes over time, with new lesions showing zonal infiltration and old lesions are characterized by perivascular infiltration [5].

Compared with LPP, ALP is even rarer, with few reports, unclear prevalence and unclear etiology [6]. It might be an independent subtype of LP or a regressive end stage of other LP types, and is seen to coexist with other types of LP damage [7]. Relevant literature was searched in the "Chinese Journal Full-text Database" and PubMed using the term "atrophic lichen planus," and analyzed 12 cases with definite diagnosis and complete clinical information, with regard to age, gender, lesion site, lesion manifestation $\varangle$ Table $1 \rrbracket$, and histopathological characteristics (Table 2). Of the 12 ALP patients, there were 5 males and 7 females, with age range from 22 to 69 years, and an average of $57.45 \pm 19.26$ years. Of these, $66.67 \%$ of the patients were middle-aged, and the disease duration ranged from 2 months to 15 years, with an average of $41.81 \pm 45.55$ months. The course of the disease is chronic and protracted. The phenotype of this disease is significantly heterogeneous and there might be multiple clinical subtypes. The skin lesions remained good on the trunk, extremities, face, feet, neck, prepuce and vulva. Most of the patients showed brown, red, purple, white, blue, yellow spots, papules and atrophic depressions on the epidermis in the center of the plaques, and only 5 cases reported Wickham's wrinkles. Histopathological features were reported in 7 cases and presented as hyperkeratosis, granulocytopenia, epidermal effacement, liquefaction degeneration of basal cells, and lichenoid infiltration. Four cases presented pigment incontinence and varying degrees of pigmented cells.

The mechanism of LP pathogenesis is related to immune dysregulation. Cytotoxic T cells, mainly CD8+ cells, promote Th1 cells to secrete cytokines with the aid of CD4 + T cells and initiate the attack on basal keratinocytes, resulting in epidermal basal layer destruction. At the same time, more $C D 8+T$ cells are recruited to the basal layer, resulting in persistent damage and leading to the chronic course of LP. The generation and differentiation of dendritic cells, regulatory $T$ cells, and multifunctional $T$ cells triggered by toll-like receptors-related innate immune responses are also involved. Upregulation of interleukin (IL)-1a, IL-6, IL-8, TNF-a, TGF- $\beta$, intercellular adhesion molecule 1 (ICAM-1), and vascular endothelial growth factor might increase microvessel density at the dermal-epidermal junction by recruiting the lymphocytes [18].

Basal cell degeneration, pigment incontinence and epidermal atrophy appear simultaneously in both LPP and ALP, and so we speculated that there is an association between the three in the pathogenesis. Epidermal atrophy mainly occurs due to retraction of epidermal processes and reduced resistance of the epidermis to shear forces, leading to reduced nutrient supply to the epidermis and might inhibit the proliferation of keratinocytes. Decreased epidermal thickness and loss of cuticular process might be related to abnormal melanocyte function, affecting the proliferation and differentiation functioning of the keratinocytes. It has been shown that senescent melanocytes induce telomere dysfunction in a paracrine manner and limit the proliferation of surrounding cells by activating mitochondrial oxidative stress. A 3D model was used to culture melanocytes with keratinocytes in vitro, in which senescent melanocytes impair the proliferation of basal keratinocytes, leading to epidermal atrophy in vitro. Studies have shown that the expression of p16, which negatively regulates cell proliferation, is significantly increased in melanocytes present in the epidermis of the elderly. A highly significant correlation between the increase of telomere-associated foci (TAF) in melanocytes and flattening of the epidermal-dermal junction is observed [19]. 
The patient was a young woman who denied other chronic diseases and did not use cosmetics or had no long-term sun exposure before disease onset. Starting from the pathogenesis of LPP and ALP, this case might be triggered by unknown external stimuli T lymphocyte-mediated immunity, resulting in interface inflammation, keratinocyte death triggered pigment incontinence, melanin granules and increased pigmented cells in the superficial dermis, and gradual appearance of epidermal atrophy with disease progression and keratinocytes were destroyed and increased.

The treatment of LP can be divided into three categories: oral drugs (acitretin, sulfapyridine, hydroxychloroquine, griseofulvin), topical creams (vitamin D analogues, corticosteroids), and phototherapy (narrow-band ultraviolet B) [20]. The classical therapeutic aim of LP is to accelerate the resolution while relieving from the pruritic symptoms. Moderate-to-high potency topical corticosteroids (TCS) are considered as the standard first-line treatment option for this. The mode of action of corticosteroid therapy is non-specific and exerted immunosuppressive and immunosuppressive effects by regulating the proinflammatory mediators at genetic, cytokine, and cellular levels. However, long-term topical corticosteroids might cause local pigmentation, epidermal atrophy, etc., while calcineurin inhibitors tacrolimus and pimecrolimus do not cause epidermal atrophy and pigmentation while inhibiting the inflammatory response [21]. How to weigh the advantages and disadvantages and reasonable dressing change remains the key to successful treatment in this case.

This is the first report to date with marked pigmented and atrophic lichen planus, which we call this as pigmented atrophic lichen planus, the etiology and mechanism of it are unclear, and it might be an independent subtype of LP or catagen phase of LPP.

\section{Declarations}

\section{Ethics approval and consent to participate:}

Not applicable.

\section{Consent for publication:}

Written informed consent for publication was obtained from all participants.

\section{Availability of data and materials:}

Not applicable.

\section{Competing interests:}

The authors declare no competing financial interests.

\section{Funding:}

This case study was supported by the grant from the National Natural Science Foundation of China (No. 81573048).

\section{Authors' contributions:}

The diagnosis and treatment of this case were completed by Dr. Zhang, and the collation of case data and summary of previous literature were completed by Dr. Liu, Dr. Zhao and Dr. Su.

\section{Acknowledgements:}

The patient is willing to share the case and has signed informed consent. 


\section{References}

1. Kanwar AJ, Dogra S, Handa S, et al. A study of 124 Indian patients with lichen planus pigmentosus. Clin Exp Dermatol. 2003;28:481-5.

2. Muthu SK, Narang T, Saikia UN, et al. Low-dose oral isotretinoin therapy in lichen planus pigmentosus: an open-label nonrandomized prospective pilot study. Int J Dermatol. 2016;55:1048-54.

3. Al-Mutairi N, El-Khalawany M. Clinicopathological characteristics of lichen planus pigmentosus and its response to tacrolimus ointment: an open label, non-randomized, prospective study. J Eur Acad Dermatol Venereol. 2010;24:535-40.

4. Robles-Méndez JC, Rizo-Frías P, Herz-Ruelas ME, Pandya AG, Ocampo Candiani J. Lichen planus pigmentosus and its variants: review and update. Int J Dermatol. 2018;57(5):505-14.

5. Sehgal VN, Verma P, Bhattacharya SN, et al. Lichen planus pigmentosus. Skinmed. 2013;11:96-103.

6. Weston G, Payette M. Update on lichen planus and its clinical variants. Int J Womens Dermatol. 2015;1(3):140-9. Published 2015 Sep 16.

7. Wagner G, Rose C, Sachse MM. Clinical variants of lichen planus. J Dtsch Dermatol Ges. 2013;11(4):309-19.

8. Li, Lin. A case of atroatroous lichen planus. Dermatovenereal diseases society of Chinese medical association and Chinese medical association. (in Chinese).

9. Zang $\mathrm{m} \mathrm{J}$. wu J h, gu J y. a case of atrophic lichen planus with ulcer. Chinese journal of leprosy dermatology,2005, (08):645. (in Chinese).

10. Ai ping. A case of atrophic lichen planus involving skin, mucous membrane and nails[A]. Chinese medical association, Chinese society of dermatology and venereology. (in Chinese).

11. Wei min, li hengjin. A case of atrophic lichen planus. Lingnan journal of dermatology and venereology,2002(03):211-212. (in Chinese).

12. Shao chengming. zhang guo-yun, wang ai-dong, zhao ya-ping, xue wei-yun, zhang ming-gong. A report of three cases of atrophic lichen planus in one family. Dermatology and veneral diseases,1992(04):36-37. (in Chinese).

13. Rustin And MHA, Munro DD. A case of atrophic lichen planus in association with Addisonian pernicious anaemia. Clin Exp Dermatol. 1986;11:188-90.

14. Roxburgh AC. Poikiloderma Jacobi: Atrophic Lichen Planus, Proc R Soc Med. 1946 Jun;39(8):479.

15. Maccormac H. Two Cases of Atrophic Lichen Planus in Girl, Proc R Soc Med. 1938 Aug;31(10):1169-70.

16. Forman L. Pigmentary and Atrophic Lichen Planus following the Administration of Arsenic and Bismuth. Proc R Soc Med. 1933 Jun;26(8):997-8.

17. Whitfield A. Atrophic Lichen Planus with Cornu Cutaneum. Proc R Soc Med. 1911;4(Dermatol Sect):11-2.

18. Tziotzios C, Lee JYW, Brier T, et al. Lichen planus and lichenoid dermatoses: Clinical overview and molecular basis. J Am Acad Dermatol. 2018;79(5):789-804.

19. Victorelli S, Lagnado A, Halim J, et al. Senescent human melanocytes drive skin ageing via paracrine telomere dysfunction. EMBO J. 2019;38(23):e101982.

20. Tziotzios C, Brier T, Lee JYW, et al. Lichen planus and lichenoid dermatoses: Conventional and emerging therapeutic strategies. J Am Acad Dermatol. 2018;79(5):807-18.

21. Bos JD. Topical tacrolimus and pimecrolimus are not associated with skin atrophy. Br J Dermatol. 2002;146(2):342-3.

\section{Tables}


Table 1

Case review of atrophic lichen planus

\begin{tabular}{|c|c|c|c|c|c|c|c|c|}
\hline Author & Age/Gender & location & Color & $\begin{array}{l}\text { Clinical } \\
\text { form }\end{array}$ & Duration & Wickham & Atrophy & Else \\
\hline $\begin{array}{l}\text { Current } \\
\text { patient }\end{array}$ & $22 / F$ & $\begin{array}{l}\text { Supramaxillary } \\
\text { area }\end{array}$ & Brown & Plaque & 6 moths & + & + & \\
\hline $\begin{array}{l}\text { Li et al. } 2014 \\
\text { [8] }\end{array}$ & $69 / F$ & $\begin{array}{l}\text { Lateral of } \\
\text { lower leg }\end{array}$ & Purple & Papule & 15 years & + & $\begin{array}{l}+ \\
\text { central }\end{array}$ & \\
\hline $\begin{array}{l}\text { Zhuang et } \\
\text { al. } 2005 \text { [9] }\end{array}$ & $65 / M$ & Prepuce & Red & $\begin{array}{l}\text { Papule } \\
\text { and ulcer }\end{array}$ & 2 year & - & + & \\
\hline $\begin{array}{l}\text { Ai et al. } \\
2012 \text { [10] }\end{array}$ & $16 / \mathrm{M}$ & $\begin{array}{l}\text { Anterior } \\
\text { cervical, chest } \\
\text { v-zone, } \\
\text { armpits, groin }\end{array}$ & $\begin{array}{l}\text { Dark } \\
\text { purple }\end{array}$ & Macule & 13 years & + & $\begin{array}{l}+ \\
\text { central }\end{array}$ & $\begin{array}{l}\text { Loss of finger- } \\
\text { nail }\end{array}$ \\
\hline $\begin{array}{l}\text { Wei et al. } \\
2002[11]\end{array}$ & $69 / \mathrm{M}$ & $\begin{array}{l}\text { Forehead } \nabla \\
\text { chest v-zone } \nabla \\
\text { back and } \\
\text { lateral side of } \\
\text { upper limbs }\end{array}$ & $\begin{array}{l}\text { Blue } \\
\text { and } \\
\text { brown }\end{array}$ & $\begin{array}{l}\text { Macule } \\
\text { and patch }\end{array}$ & 1 year & + & + & \\
\hline $\begin{array}{l}\text { Shao et al. } \\
1992 \text { [12] }\end{array}$ & $32 / F$ & $\begin{array}{l}\text { Face and back } \\
\text { of hand }\end{array}$ & $\begin{array}{l}\text { Reddish } \\
\text { brown }\end{array}$ & Patch & 6 years & / & $\begin{array}{l}+ \\
\text { central }\end{array}$ & Family history \\
\hline $\begin{array}{l}\text { Rustin et al. } \\
1986 \text { [13] }\end{array}$ & $54 / F$ & $\begin{array}{l}\text { Thigh } \nabla \text { upper } \\
\text { arms } \nabla \text { neck } \bigotimes \\
\text { trunk }\end{array}$ & $\begin{array}{l}\text { Lemon- } \\
\text { yellow }\end{array}$ & $\begin{array}{l}\text { Annular } \\
\text { lesions }\end{array}$ & $\begin{array}{l}8 \\
\text { months }\end{array}$ & / & + & $\begin{array}{l}\text { Addisonian } \\
\text { pernicious } \\
\text { anaemia }\end{array}$ \\
\hline $\begin{array}{l}\text { Roxburgh } \\
1946[14]\end{array}$ & $57 / \mathrm{M}$ & $\begin{array}{l}\text { Forearms, feet } \\
\text { and ankles }\end{array}$ & Red & $\begin{array}{l}\text { Shiny } \\
\text { polygonal } \\
\text { islands }\end{array}$ & 1 year & / & + & \\
\hline $\begin{array}{l}\text { Davis } 1938 \\
\text { [15] }\end{array}$ & $55 / F$ & Clavicle邓thigh & White & Spots & 5 years & / & + & Needle-prick \\
\hline $\begin{array}{l}\text { Davis } 1938 \\
\text { [15] }\end{array}$ & $62 / F$ & $\begin{array}{l}\text { Vulva } \rrbracket \\
\text { forearms } \\
\text { thighs and } \\
\text { anal }\end{array}$ & White & Spots & 5 years & / & + & \\
\hline $\begin{array}{l}\text { Forman1933 } \\
\text { [16] }\end{array}$ & $27 / M$ & $\begin{array}{l}\text { Chest, trunk, } \\
\text { proximal part } \\
\text { of the limbs, } \\
\text { face and scalp }\end{array}$ & $\begin{array}{l}\text { Red } \\
\text { then } \\
\text { brown }\end{array}$ & Patch & $\begin{array}{l}2 \\
\text { months }\end{array}$ & + & + & $\begin{array}{l}\text { Administration } \\
\text { of arsenic and } \\
\text { bismuth }\end{array}$ \\
\hline $\begin{array}{l}\text { A. Whitfiled } \\
1911 \text { [17] }\end{array}$ & $63 / F$ & Below the knee & $\begin{array}{l}\text { Bluish- } \\
\text { red }\end{array}$ & $\begin{array}{l}\text { Network } \\
\text { and the" } \\
\text { holes" } \\
\text { were } \\
\text { composed } \\
\text { of pearly } \\
\text { atrophy }\end{array}$ & 4 years & + & + & \\
\hline
\end{tabular}


Table 2

Histopathology of atrophic lichn planus

\begin{tabular}{|c|c|c|c|c|}
\hline Author & $\begin{array}{l}\text { Hyperpigmen- } \\
\text { tation }\end{array}$ & Melanophages & $\begin{array}{l}\text { Pigmentary } \\
\text { incontinence }\end{array}$ & Histopathology \\
\hline $\begin{array}{l}\text { Current } \\
\text { patient }\end{array}$ & + & + & + & $\begin{array}{l}\text { Keratinization, lichenoid lymphocytic infiltrate冈incontinence } \\
\text { of pigment囚numerous of melanophages }\end{array}$ \\
\hline $\begin{array}{l}\text { Lin et al. } \\
2014[8]\end{array}$ & + & + & + & Lichenoid infiltrate \\
\hline $\begin{array}{l}\text { Zhuang et } \\
\text { al. } 2005 \\
\text { [9] }\end{array}$ & - & - & - & 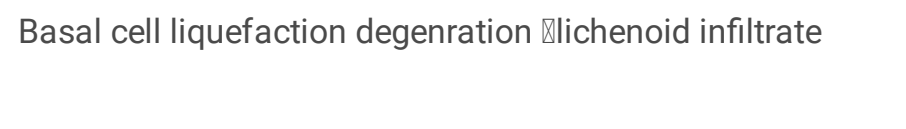 \\
\hline $\begin{array}{l}\text { Ai et al. } \\
2012[10]\end{array}$ & + & + & + & $\begin{array}{l}\text { Hyperkeratosis, follucylar plug,basal cell liquefaction } \\
\text { degenration }\end{array}$ \\
\hline \multirow[t]{2}{*}{$\begin{array}{l}\text { Wei et al. } \\
2002[11]\end{array}$} & + & + & + & $\begin{array}{l}\text { Slightly hyperkeratosis 囚epidermal ridges disappear } \text { \basal } \\
\text { cell liquefaction degenration } \rrbracket\end{array}$ \\
\hline & & & & Lichenoid infiltrate \\
\hline $\begin{array}{l}\text { Shao et } \\
\text { al. } 1992 \\
\text { [12] }\end{array}$ & - & - & - & Hyperkeratosis $₫$ hypogranulosis $\bigotimes$ lichenoid infiltrate \\
\hline $\begin{array}{l}\text { Rustin et } \\
\text { al. } 1986 \\
\text { [13] }\end{array}$ & - & - & - & $\begin{array}{l}\text { Hypergranulosis and hyperkeratosis } ₫ \text { degeneration of the } \\
\text { basal layer冈lichenoid infiltrate }\end{array}$ \\
\hline $\begin{array}{l}\text { Forman } \\
1933[16]\end{array}$ & + & + & + & $\begin{array}{l}\text { Well-marked granular layer and slight } \\
\text { hyperkeratosis,lymphocytic infiltrate on basal layer, mainly } \\
\text { leucocytic infiltration around the vessels }\end{array}$ \\
\hline
\end{tabular}

\section{Figures}
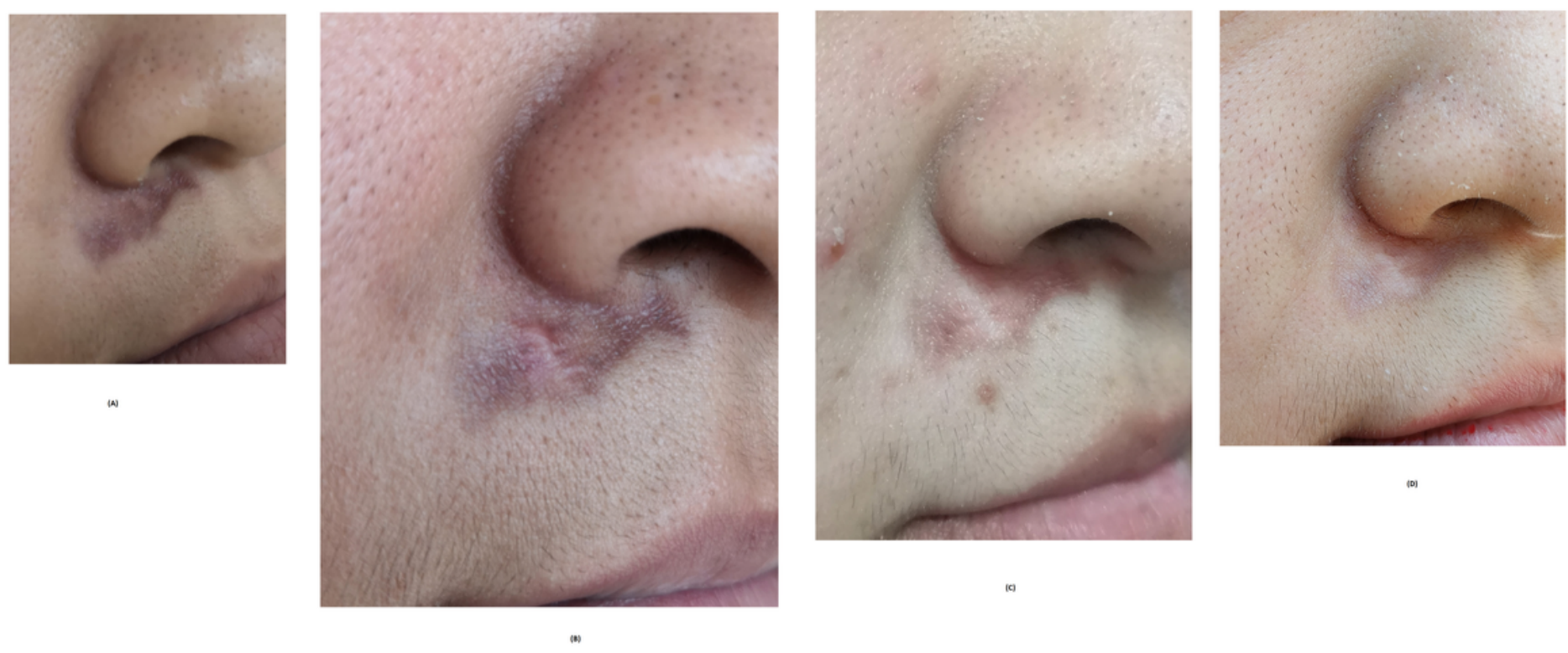

(D)

\section{Figure 1}

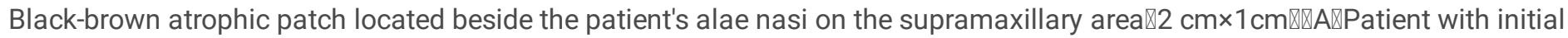
encounter; (B) after 2 months of calcineurin inhibitor treatment, symptoms were improved but no significant changes were 
observed in skin lesions; $\mathbb{X}$ \after 4 months of local treatment with glucocorticoids, the plaque color has been changed and the area was decreased by $50 \%$; (D) after 10 months of treatment, the skin lesion was improved without atrophy or pigmentation.

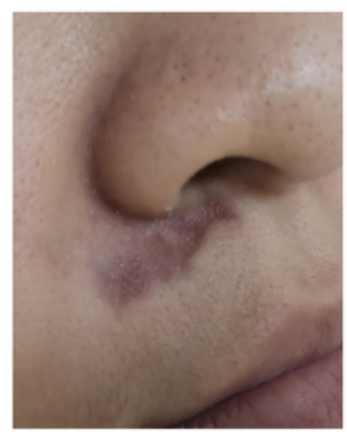

(w)

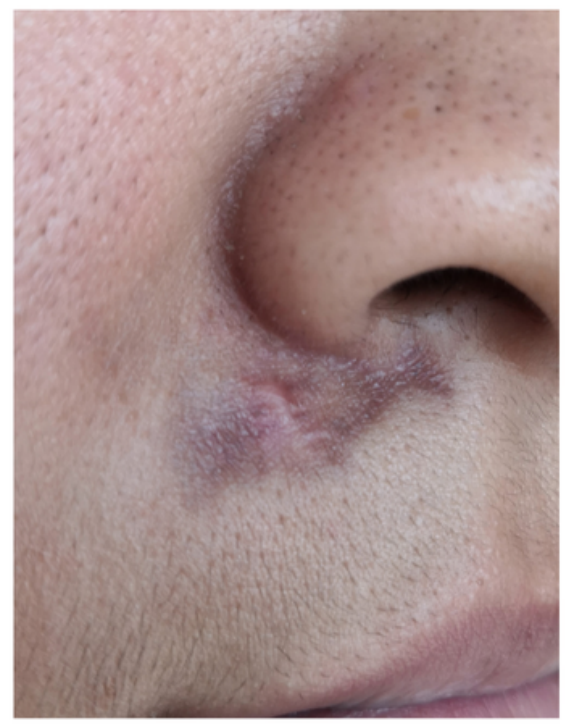

(4)
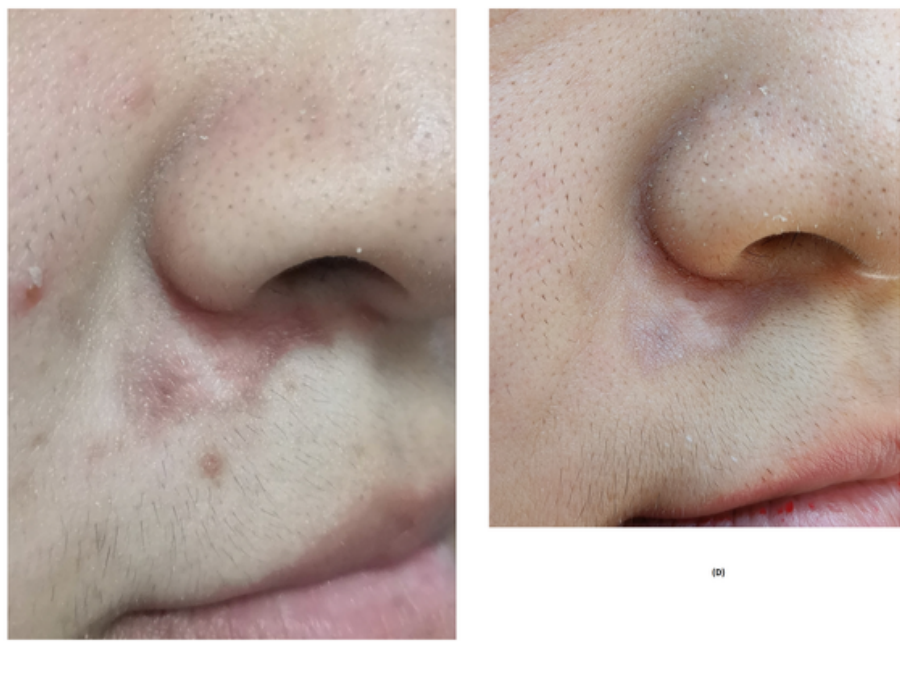

(0)

\section{Figure 1}

Black-brown atrophic patch located beside the patient's alae nasi on the supramaxillary area $\mathbb{2} \mathrm{cm} \times 1 \mathrm{~cm} \otimes \mathbb{A} \llbracket \mathrm{Patient}$ with initial encounter; (B) after 2 months of calcineurin inhibitor treatment, symptoms were improved but no significant changes were observed in skin lesions; $\mathbb{C} \mathbb{\triangle}$ after 4 months of local treatment with glucocorticoids, the plaque color has been changed and the area was decreased by $50 \%$; (D) after 10 months of treatment, the skin lesion was improved without atrophy or pigmentation.

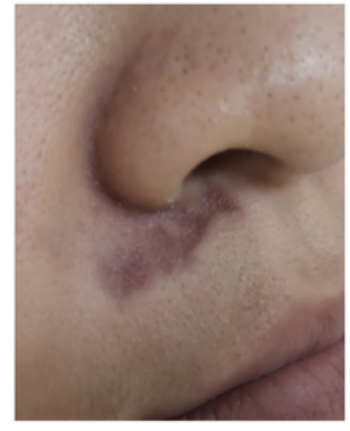

(N)

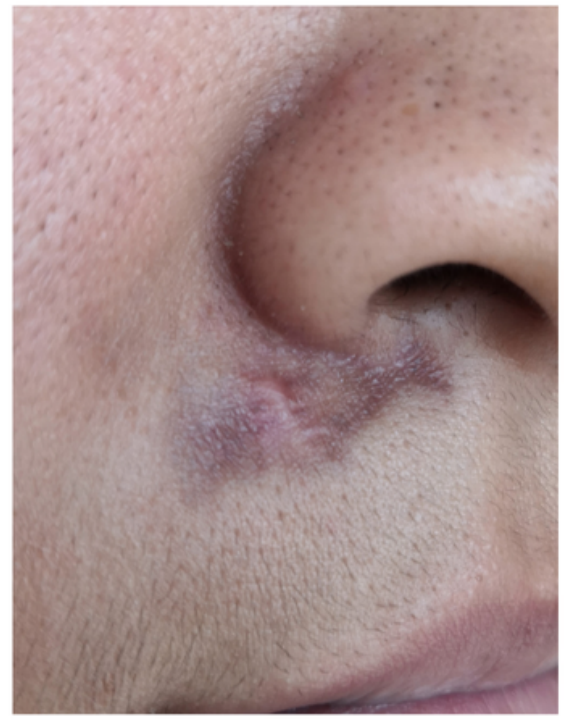

(i)
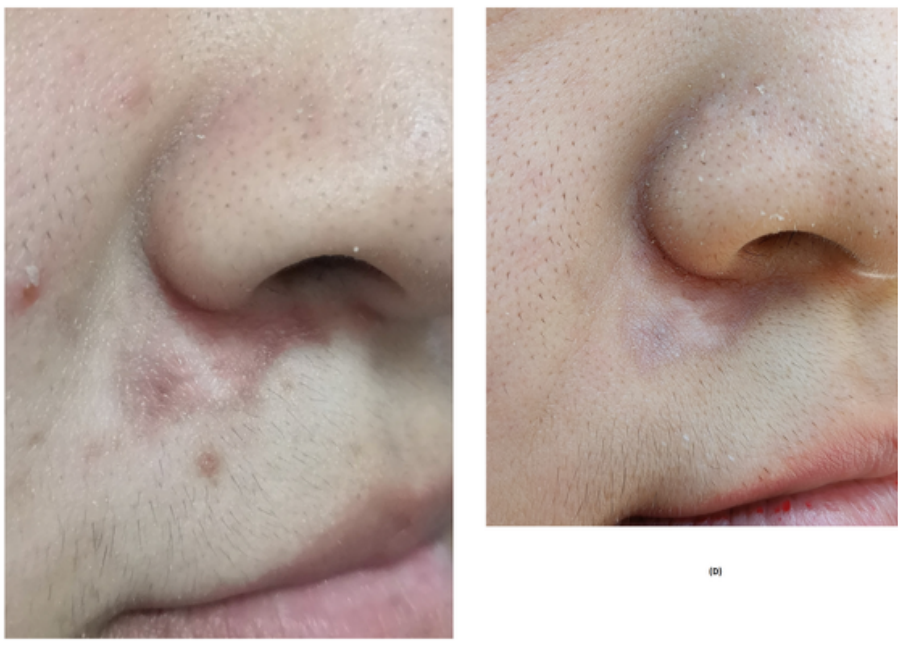

(0)

\section{Figure 1}

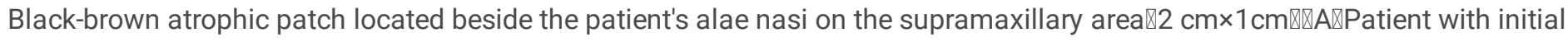
encounter; (B) after 2 months of calcineurin inhibitor treatment, symptoms were improved but no significant changes were observed in skin lesions; $₫ \mathrm{C} \rrbracket$ after 4 months of local treatment with glucocorticoids, the plaque color has been changed and the area was decreased by $50 \%$; (D) after 10 months of treatment, the skin lesion was improved without atrophy or pigmentation. 


\section{Figure 2}

Microscopically, mixed manifestations of LPP and ALP were observed, with epidermal atrophy, loss of epidermal processes,

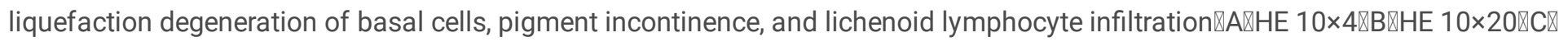
HE 10×20هDखHE 10×4
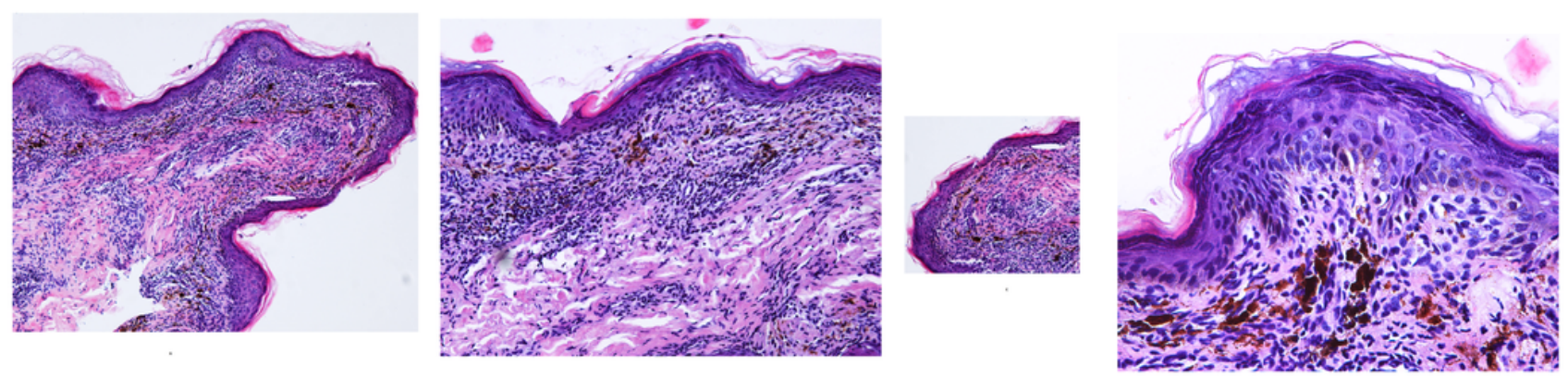

\section{Figure 2}

Microscopically, mixed manifestations of LPP and ALP were observed, with epidermal atrophy, loss of epidermal processes, liquefaction degeneration of basal cells, pigment incontinence, and lichenoid lymphocyte infiltration $₫ A \otimes H E 10 \times 4 \rrbracket B \otimes H E 10 \times 20 \otimes C \otimes$ HE 10×20هDषHE 10×4
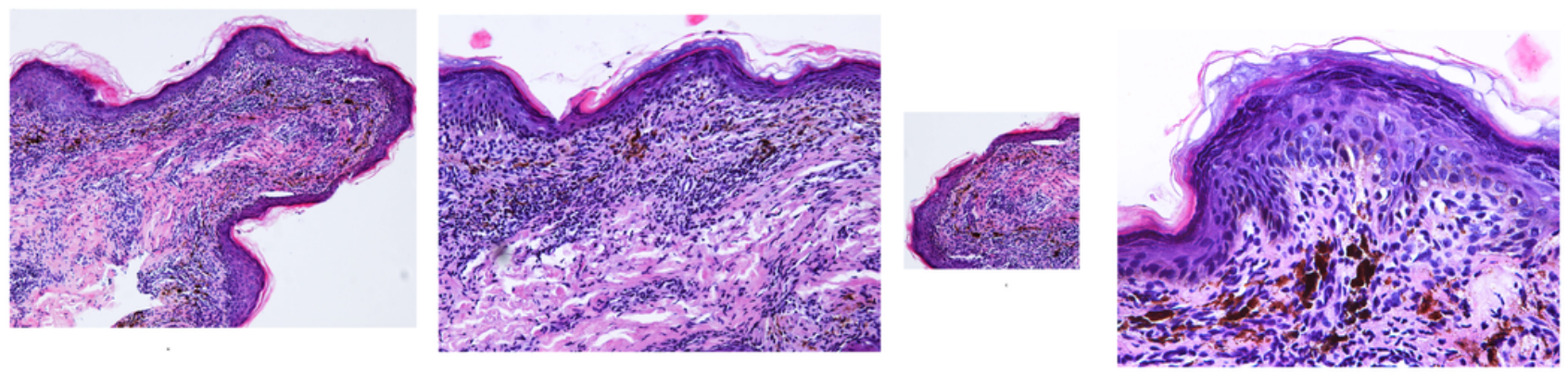

\section{Figure 2}

Microscopically, mixed manifestations of LPP and ALP were observed, with epidermal atrophy, loss of epidermal processes,

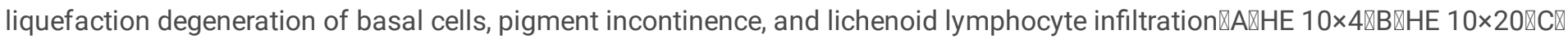




\section{Supplementary Files}

This is a list of supplementary files associated with this preprint. Click to download.

- CAREChecklistPALP.docx

- CAREChecklistPALP.docx

- CAREChecklistPALP.docx

- summaryslide.pptx

- summaryslide.pptx

- summaryslide.pptx 